Journal of Engineering Sciences, Assiut University, Vol. 37, No. 3, pp. 521 -541 , May 2009,

\title{
NONLINEAR LATERAL RESPONSE OF MASONRY INFILLED RC BUILDINGS WITH VARIABLE PARAMETERS
}

\author{
Waleed Abo El-Wafa Mohamed \\ Lecturer, Civil Engineering Department, Faculty of Engineering, Assiut \\ University, Assiut, Egypt.
}

(Received April 26, 2009 Accepted May 5 , 2009)

\begin{abstract}
Masonry infill (MI) walls confined by Reinforced concrete (RC) frames play a crucial role, either positive or negative, in altering the lateral capacity of buildings they are applied to. In this study, a nonlinear numerical investigation on the lateral behavior of masonry infilled $R C$ buildings is carried out. Variety of parameters for both MI walls and buildings are considered. Different configurations of MI walls, size of wall openings, absence of MI walls in the first storey and MI wall thickness are investigated. The application buildings are either moment resisting frames (MRF) or dual shear wall-moment resisting frames (SW-MRF) buildings. The MRF buildings have 6 floors, while the SW$M R F$ buildings have 5 different heights represented by the number of floors (from six to twenty floors). Equivalent strut methodology is used and modified to model the behavior of infill walls taking into consideration the effect of opening sizes. Nonlinear static push-over analysis is carried out for the applied case study buildings. It is found that MI walls can highly increase the base shear capacity of either building types while significantly reduce the displacement capacity of $M R F$ buildings, RC shear walls can resist this negative effect. The existence of soft first storey can drastically alter the lateral response of buildings. The influence of MI walls fade as the building height increases. The new distribution of failure mechanism is introduced.
\end{abstract}

KEYWORDS: masonry infill walls, push-over analysis, wall openings, soft storey, seismic codes

\section{INTRODUCTION}

Masonry infill walls are widely used in most existing RC buildings around the world. This wide spread is related to the economical mean they provide to divide and enclose spaces to any required purposes. In regions with seismicity history or even high wind speeds, the lateral loads due to earthquakes or wind loads are the prevailing forces that require, rather than the ordinary gravity loads, special attention in assessing the behavior of such buildings. The structural contribution of masonry infill walls to the buildings they are implemented in is seldom included in the analysis and design of such structures [1] - [3]. This ignorance occurs although many experiments on RC frame buildings confining masonry infill walls show that infill walls have a high initial lateral stiffness and low deformability. The contribution of masonry infills may change the lateral load transfer mechanism of the structure from predominant frame actions to 
predominant truss actions. [1], [4]. The reality that the infill walls have significant contribution to the lateral performance of RC structures, either in a positive or negative way, and can highly alter the structural response of buildings was highly supported and illustrated by the performance of buildings in the recent earthquakes (e.g., 1985 Mexico City, 2001 Bhuj (India) and 1999 Kocaeli (Turkey) earthquakes) [5] , [6].

Behavior of MI walls is difficult to be predicted because of significant variations in material properties that can be used in the manufacturing of MI walls and different configurations by which they can be applied to buildings [4], [7]. The presence of openings, such as doors and windows, in MI walls can decrease stiffness and strength of infilled frames and hence change the expected behavior [5]. A large number of residential and commercial buildings had soft stories at the first-floor level due to the absence of MI walls in this storey, inside and on the sides of main streets. This happens because the first stories have been often used for shopping and commercial purposes, heavy MI walls start immediately above the soft storey. Inspections of last earthquake damages, as well as the results of some analytical studies, have shown that structural systems with a soft storey can lead to serious problems during severe earthquake ground shaking. The presence of a soft storey may result in increased deformation demands significantly, and puts the burden of energy dissipation on the first-storey columns. [6], [8], [9].

To deal with the subject of MI walls, various national codes can be broadly grouped in two categories of those that consider or do not consider the role of MI walls while designing RC frames. A very few codes specifically recommend isolating the MI walls from the RC frames such that the stiffness of MI does not play any role in the overall stiffness of the frame. As a result, MI walls are not considered in the analysis and design procedure. The isolation helps to prevent the problems associated with the brittle behavior and asymmetric placement of MI walls. Another group of national codes prefer to take advantage of certain characteristics of MI walls such as high initial lateral stiffness, cost-effectiveness, and ease in construction. These codes require that the beneficial effects of MI walls are appropriately included in the analysis and design procedure and that the detrimental effects are mitigated. In other words, these codes tend to maximize the role of MI walls as a first line of defense against seismic actions, and to minimize their potential detrimental effects through proper selection of their layout and quality control [4]. The Egyptian Code of Loads (September 2008) [10] renewed some general provisions related to the MI walls (called in this code Nonstructural elements NSE). These provisions include that if the NSE are with risk impact on causalities or affect the main structure of building, they must be designed to resist seismic loads. If the NSE are with high importance or risk, the seismic analysis of the structure should include real representation of all building components. Also, the 2008 ECOL relates the interstorey drift limitations to the type of NSE (whether brittle, ductile or isolated). No provisions related to modeling of MI walls, effect of openings or soft stories are presented in this new edition of code.

The subject of masonry infilled reinforced concrete frames had attracted many researchers over the past five decades. There effort have been paid in many areas related to this subject such as modeling and idealization of infill walls [11], [12], experimental investigations [13], [14], modeling infill openings as windows and doors [5], [15], natural period of infilled frames [16], [17] and numerical investigations [18]-[21]. However, certain areas still need further investigations. Among the research 
needs identified were (1) the influence and interaction of some MI parameters (i.e., wall configuration, opening size, wall thickness and existence of soft stories); (2) the interaction between MI and RC shear walls; (3) the influence of building height on the response of frames with MI walls; and (4) redistribution of plastic hinges.

The main purpose of this study is to analytically investigate the nonlinear lateral behavior of masonry infilled reinforced concrete buildings. The investigated example buildings are either moment resisting frames MRF or dual system consists of shear walls and moment resisting frames SW-MRF buildings. The effect of many parameters of MI walls on the seismic response of RC masonry infilled buildings are considered. These parameters include different configurations of infills, variable opening sizes, MI wall thickness and the existence of first soft storey. The interaction between masonry infills and RC shear walls on buildings with different heights is evaluated through analyzing the example SW-MRF buildings with different five heights represented by the number of floors which ranges between six and twenty floors. The infill masonry walls are idealized using the equivalent strut methodology taking into consideration the effect of openings, the nonlinear hinge models available in the ETABS software [22] are modified to account for the specific behavior of MI walls. Nonlinear push-over analysis is carried out to assess the behavior of the MIRC buildings with the different studied parameters, the results are introduced in the form of normalized base shear-lateral displacement curves. The propagation and formation of plastic hinges for sample buildings are also discussed.

\section{DESCRIPTION AND DESIGN OF EXAMPLE BUILDINGS}

All the studied buildings have almost the same plan features as shown in Fig. 1. The buildings are with plan dimensions of $25.0 \mathrm{~m}$ in the longitudinal direction and $18.0 \mathrm{~m}$ in the lateral direction. The typical bay dimensions are $5.0 \mathrm{~m}$ and $6.0 \mathrm{~m}$ in the mentioned preceded directions, respectively. Different building heights represented by the number of floors are considered in this study, 6, 9, 12, 16 and 20 floor buildings are analyzed. For all buildings the height of the first floor is equal to $4.0 \mathrm{~m}$, while the height of the typical remaining floors are $3.0 \mathrm{~m}$, sample elevation is shown in Fig 2.

The gravity load resisting system consists of solid slabs supported by beams, columns and shear walls (if exist). Two different lateral load resisting systems are considered. These systems are dual reinforced concrete shear wall-frame system SW-MRF, which is applied to the considered building with all different heights, beginning from 6 floors to 20 floors. The other MRF system is assigned only for buildings with height equivalent to 6 floors and depends on the frame action generated from the connection between beams and columns.

All the studied buildings are designed according to the requirements of the 2008 ECOL. All the studied buildings are assumed to be located in seismic region 3 which is remarkable with acceleration equal $0.15 \mathrm{~g}$ and type 1 response spectra which is specified for regions other than coastal regions along the Mediterranean sea. The subsoil on which the buildings are founded is considered to be of class $\mathrm{C}$. The equivalent static load method using the horizontal design spectra for elastic analysis is used, a reduction due to the capability of the structure to resist seismic forces in the plastic range is applied. 
The considered loads are the dead loads of the building, superimposed dead load of $1.5 \mathrm{KN} / \mathrm{m}^{2}$ and live load equal $2.5 \mathrm{KN} / \mathrm{m}^{2}$. The dead load of walls is applied directly on beams. The loads which are considered in the seismic design of buildings are the full dead loads plus $50 \%$ of the live loads [10]. The beams are designed to have a section of $0.2 \times 0.6 \mathrm{~m}$ for buildings with 6 and 9 floors and $0.25 \times 0.6 \mathrm{~m}$ for buildings with other heights. The column sections are varying with different height buildings and along their heights. The sections of columns on the first floor for the buildings with different heights are shown in Table 1. Buildings with number of floors equal 6, either MRF or SW-MRF buildings have the same columns sections while a reduction in column reinforcement may be applied to SW-MRF buildings.

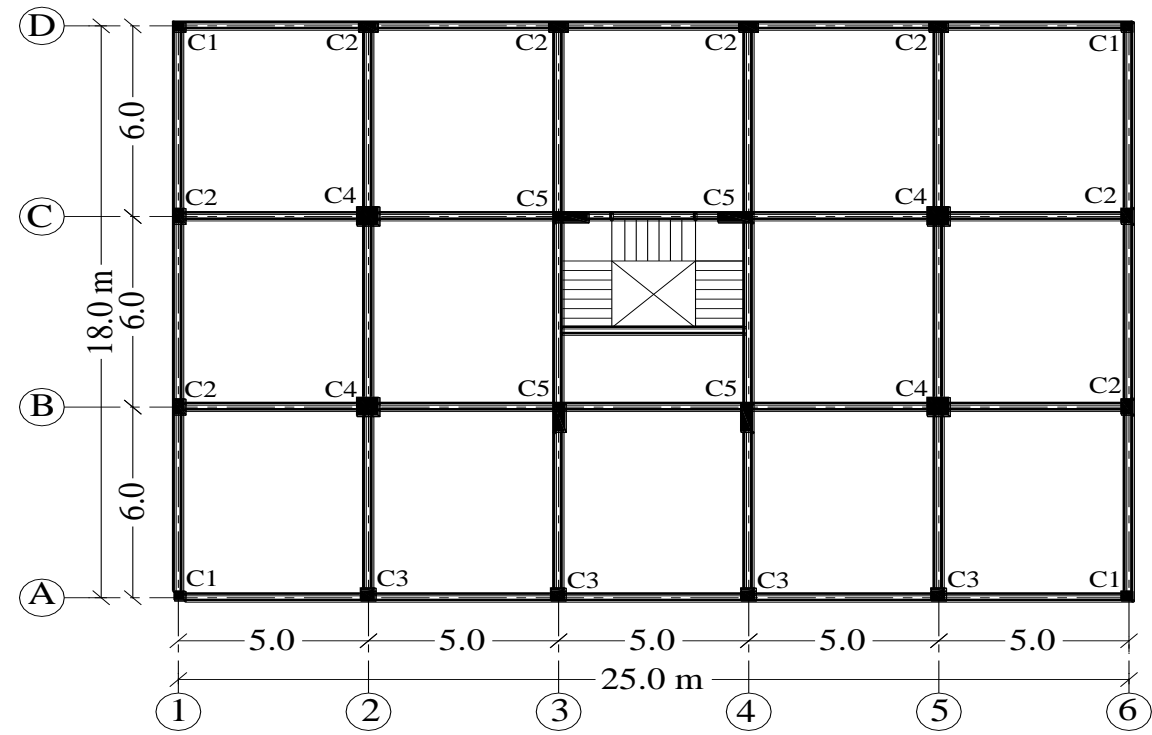

Fig. 1: General plan of the investigated MRF building

The effective total lengths of shear walls in the first storey in each orthogonal direction $\left(L_{w}\right)$ is designed to meet the mentioned seismic requirements and is taken as a ratio of the total height of building. This ratio $\left(L_{w} / H\right)$ is 0.20 for walls along the short direction and 0.165 for walls situated in the longitudinal direction. The thickness of shear walls is taken $0.2 \mathrm{~m}$. The position of shear walls for buildings with different heights are shown in Fig. 3. The compressive strength of used concrete is $25.0 \mathrm{MPa}$ while the used steel is high tensile with yield strength of $400 \mathrm{MPa}$. The MI walls have modulus of elasticity equal 5.0 GPa and strength of 4.0 MPa.

Table 1: Dimensions of columns (m) in the first floor.

\begin{tabular}{|l||c||c|c|c|c||}
\hline \multicolumn{1}{|c|}{ Col. model } & C1 & C2 & C3 & C4 & C5 \\
\hline \hline Dim. (6 floors) & $0.30 \times 0.30$ & $0.30 \times 0.50$ & $0.40 \times 0.40$ & $0.60 \times 0.60$ & $0.30 \times 0.90$ \\
\hline Dim. (9 floors) & $0.30 \times 0.45$ & $0.30 \times 0.65$ & $0.45 \times 0.45$ & $0.65 \times 0.65$ & $0.30 \times 1.00$ \\
\hline \hline Dim. (12 floors) & $0.30 \times 0.55$ & $0.30 \times 0.95$ & $0.55 \times 0.55$ & $0.75 \times 0.75$ & $0.30 \times 1.25$ \\
\hline Dim. (16 floors) & $0.30 \times 0.75$ & $0.30 \times 1.15$ & $0.60 \times 0.60$ & $0.90 \times 0.90$ & $0.30 \times 1.35$ \\
\hline Dim. (20 floors) & $0.40 \times 0.75$ & $0.40 \times 1.15$ & $0.70 \times 0.70$ & $1.00 \times 1.00$ & $0.40 \times 1.50$ \\
\hline
\end{tabular}




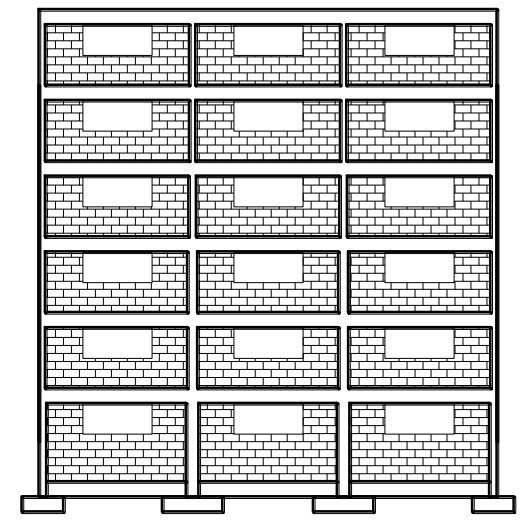

Fig. 2: Elevation of sample external walls (6 floors building)

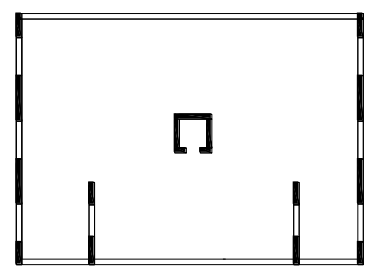

6 floors

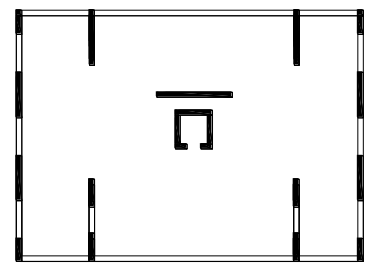

16 floors

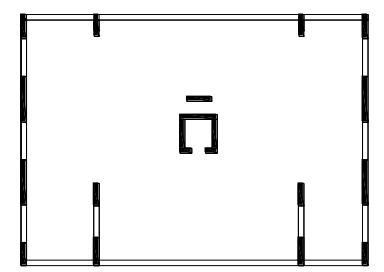

9 floors

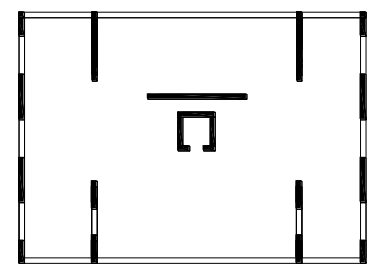

20 floors

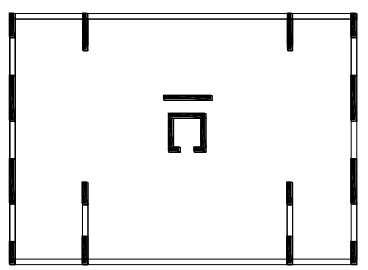

12 floors

- MI

- SW

Fig. 3: Positions of RC shear and sample MI walls for buildings with different heights

\section{MODELING APPROACH AND CODE PROVISIONS}

The MI walls, which are enclosed by two columns and two beams, are usually modeled as equivalent diagonal compression strut as shown in Fig 4. Dealing with the equivalent strut methodology, the Eurocode-8 [23] specifies that shear capacity of columns is required to be checked and recommended a strut width of an unspecified fraction of the panel diagonal length. FEMA-306 [24] recommends the following equations, which are based on the early studies of Mainstone [12] and Smith [11] to calculate the properties of diagonal compression strut:

$$
A_{e}=w_{e} t
$$


where $w_{e}=0.175(\lambda h)^{-0.4} \sqrt{h^{2}+l^{2}}$

where $\lambda=\sqrt[4]{\frac{E_{i} t \sin (2 \theta)}{4 E_{c} I_{c} H_{i}}}$

$A_{e}$ and $w_{e}$ are area and width of strut, respectively. $h$ and $l$ are the height and length of the frame panel, respectively, $E_{c}$ and $E_{i}$ are the elastic moduli of the column and of the infill panel, respectively, $t$ is the thickness of the infill panel, $\theta$ is the angle defining diagonal strut, $I_{c}$ is the moment of inertia of the column and $H_{i}$ is the height of the infill panel. In the present study the above mentioned procedure recommended by FEMA-306 is used in idealizing the behavior of solid masonry infills.

The properties of the equivalent diagonal strut, which represents the MI wall, under lateral loadings, change due to the existence of openings such as doors and windows. Generally, most national codes do not include the effect of openings on the stiffness and strength of MI walls or present procedures about how to model wall openings. Eurocode- 8 specifies that only the solid walls or walls with a single door or window opening are assumed to be imparting any significant strength to the structure and gives some details about the openings. However, researches state that the two main parameters affecting the properties of equivalent strut represents infill walls with openings are size and position of opening. In this study, the effect of opening is considered using a stiffness reduction factor $\lambda$ which varies according to the two mentioned parameters. This factor can be obtained from graphs presented by Asteris [15]. The final infill wall, with opening, area is the product of the area obtained in Eq. 1 and the stiffness reduction factor $\lambda$.

To carry out the nonlinear push-over analysis, the nonlinear hinge properties of equivalent strut is idealized using force displacement constitutive law suggested by FEMA-273 [25] for members subjected to axial forces. This axial force model is modified for the infill walls to account for the weak behavior of infill walls in tension which is only about $20 \%$ its compressive capacity [7]. Beams and columns are also assigned nonlinear hinge properties suggested by FEMA-273 depending on their moment capacity. As no plastic hinges can be applied to shell elements in ETABS, the stiffness of shear walls are modified by a factor equal 0.5 to account for their nonlinear behavior [10].
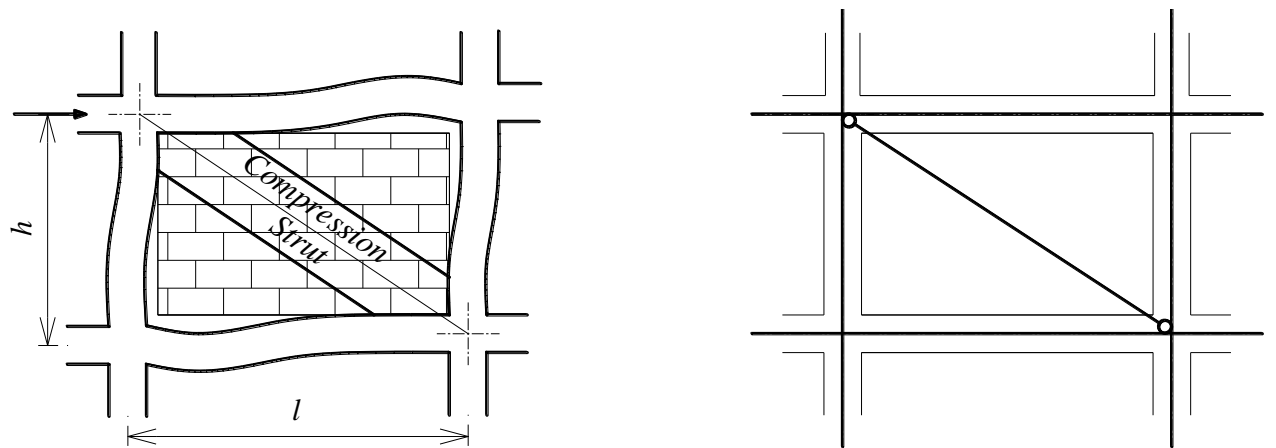

Fig. 4: Modeling of reinforced concrete frame with MI walls 


\section{4- CONSIDERED PARAMETERS}

To investigate the nonlinear lateral behavior of the masonry infilled frames in comparison with the corresponding bare frame cases, a variety of parameters should be considered. These parameters may be related to the infill walls or the building itself. In this study, the considered parameters include the configuration of infill panels, the opening ratio in each infill panel, the soft first storey, the thickness of masonry infill walls and finally, the total height of the considered building.

The configuration of MI walls is represented by the ratio between the number of panels fully occupied with infill walls to the ratio of the total number of panels in the specified direction $\left(\mathrm{N}_{\mathrm{i}} / \mathrm{N}_{\mathrm{t}}\right)$. In this study, the lateral short direction is considered. Three different infill configurations are studied which are represented by infilled panels to total panels ratio $\left(\mathrm{N}_{\mathrm{i}} / \mathrm{N}_{\mathrm{t}}\right)$ of $33.33 \%, 44.44 \%$ and $66.67 \%$, respectively. Buildings with $\left(\mathrm{N}_{\mathrm{i}} / \mathrm{N}_{\mathrm{t}}\right)$ equal to $44.44 \%$ are shown in Fig. 3.

Due to the crucial role that can be played by the openings in infill walls, three different common opening sizes are to be applied to each considered infill panel with opening. The height of openings are kept fixed and equal to $1.2 \mathrm{~m}$ while the width of opening is assigned to be $1.2 \mathrm{~m}, 2.0 \mathrm{~m}$ or $4.0 \mathrm{~m}$. These openings are located in almost a central position and gives stiffness reduction factor to be multiplied by the infill equivalent strut area of $60 \%, 40 \%$ and $20 \%$, respectively.

The absence of infill walls in the first floor (soft first storey) as the case in many buildings at which the first floor is assigned to be an open area without any partitions for different commercial purposes is also studied.

As it is very common in Egypt to use MI walls of bricks having width equal to $0.12 \mathrm{~m}$ or $0.2 \mathrm{~m}$, the effect of using either of the two brick thicknesses is investigated (unless mentioned, walls with thickness $0.12 \mathrm{~m}$ is considered)

Finally, the lateral behavior of the infilled frames in comparison with the corresponding bare frames over different heights is investigated to discuss the interaction between RC and MI walls. This is attained by analyzing the example buildings with different heights represented by the number of floors. The considered number of floors of the example buildings are 6, 9, 12, 16 and 20 floors.

The results of the nonlinear push-over analysis are introduced in the form of normalized base shear-displacement curves, this is along with discussing the mechanism and formation of plastic hinges of different studied cases.

\section{5- NONLINEAR ANALYSIS OF 6 FLOOR BUILDINGS}

The nonlinear push-over analysis of the 6 floor buildings with either lateral load resisting systems, moment resisting frame (MRF) and dual shear wall-frame system (SW-MRF), is carried out to assess the effect of the considered infill parameters. The following notations are used:

$O B F$ : The original bare frame without MI walls.

$R 33, R 44$ and R66: The number of bays occupied with MI to total bay numbers in the lateral direction $\left(\mathrm{N}_{\mathrm{i}} / \mathrm{N}_{\mathrm{t}}\right)$ is equal to $33.33 \%, 44.44 \%$ and $66.67 \%$, respectively.

R44-20, R44-40 and R44-60: Buildings with $\left(\mathrm{N}_{\mathrm{i}} / \mathrm{N}_{\mathrm{t}}\right)$ equal to $44.44 \%$, the MI walls have openings result in stiffness reduction factor $\lambda$ of $20 \%, 40 \%$ and $60 \%$, respectively. 
R33-40S, R44-40S and R66-40S: Soft first storey buildings having MI walls with openings yield $\lambda$ of $40 \%,\left(\mathrm{~N}_{\mathrm{i}} / \mathrm{N}_{\mathrm{t}}\right)$ equal $33.33 \%, 44.44 \%$ and $66.67 \%$, respectively. $9 F, 12 F, 16 F$ and $20 F$ : The number of floors are $9,12,16$ and 20, respectively.

The effect of different MI solid walls, without openings, configurations represented by $\left(\mathrm{N}_{\mathrm{i}} / \mathrm{N}_{\mathrm{t}}\right)$ values equal $33.33 \%, 44.44 \%$ and $66.67 \%$ is studied. The nonlinear push-over analysis curves for both MRF and SW-MRF buildings are shown in Figs. 5 and 6. It can be observed that comparing the nonlinear behavior of the $O B F$ buildings with the normalized (V/W) design values obtained from the $2008 \mathrm{ECOL}$ leads to that the first yield (V/W) value of the $O B F$ is about 2.06 times the code design value for the MRF while it is about 1.59 for the SW-MRF buildings. Existence of RC shear walls influences an increase in the slope of the push-over curve for SW-MRF building in comparison with the MRF building which exhibits push-over curve with almost horizontal slope. This behavior results in at failure (V/W) value about 3.8 times the design one for MRF building, while it is about 4.06 for SW-MRF building.

The MI walls have a pronounced effect on the lateral response of the studied frames. Generally, the presence of MI walls increases the stiffness of the building, represented by $(\mathrm{V} / \mathrm{W})$, relying on the infill configuration and type of building. MI walls applied to MRF building could increase the maximum normalized base shear relative to the values of the corresponding $O B F$ with ratios equal to $113.23 \%, 80.25 \%$ and $50.12 \%$ for different $\left(\mathrm{N}_{\mathrm{i}} / \mathrm{N}_{\mathrm{t}}\right)$ values equal $66.67 \%, 44.44 \%$ and $33.33 \%$, respectively. Similar trends could by observed for SW-MRF buildings but with percentage increase of $84.11 \%, 60.55 \%$ and $55.28 \%$ for the same preceded configurations, respectively.

In contrary to the gain in the stiffness associated with the consideration of MI walls, there is a notable reduction in the ductility, relative to $O B F$ for MRF building. The accounted reduction in peak nonlinear displacement relative to the corresponding value of $O B F$ is not less than $35.5 \%$ and almost independent of the configurations. This high reduction in lateral displacement could negatively alter the lateral response of building by shifting the building performance points or may lead to the incapability of the building to meat appropriate performance point when subjected to high lateral loads. It is evident from the shown figures that the existence of shear walls could highly control the reduction of ductility expected to the masonry infilled SW-MRF building, the reduction in maximum displacement capacity of these cases relative to the same $O B F$ building does not exceed $7.91 \%$. For these SW-MRF buildings, the peak displacement capacity is so close for the different studied configurations.

As it is practical to have openings in the MI walls with different sizes, the lateral response of the case study buildings with openings having different sizes is analyzed. For brevity, only the results of configuration $R 44$ with different opening sizes are displayed in comparison with the same configuration with solid MI walls as shown in Figs. 7 and 8. It is clear that the existence and size of openings have an importance on both strength and ductility of masonry infilled MRF buildings. The peak building displacement capacity increases as the opening size increases. The percentage increase relative to the same configuration without openings are $7.75 \%, 21.62 \%$ and $43.68 \%$ for opening sizes corresponding to stiffness reduction factors of $60 \%, 40 \%$ and $20 \%$, respectively. 


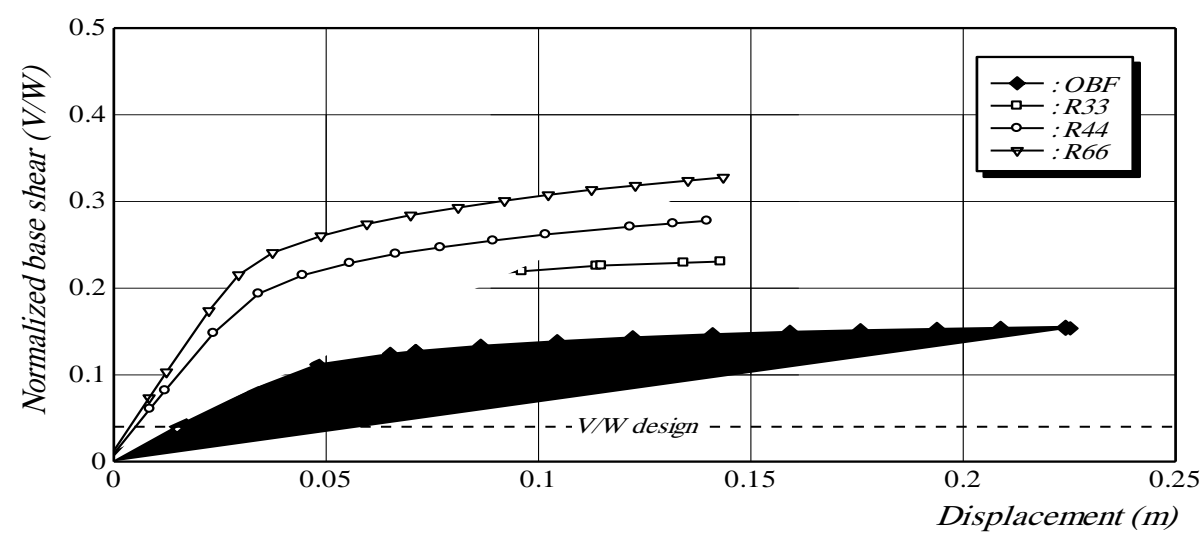

Fig. 5 : Effect of MI wall configurations (MRF building)

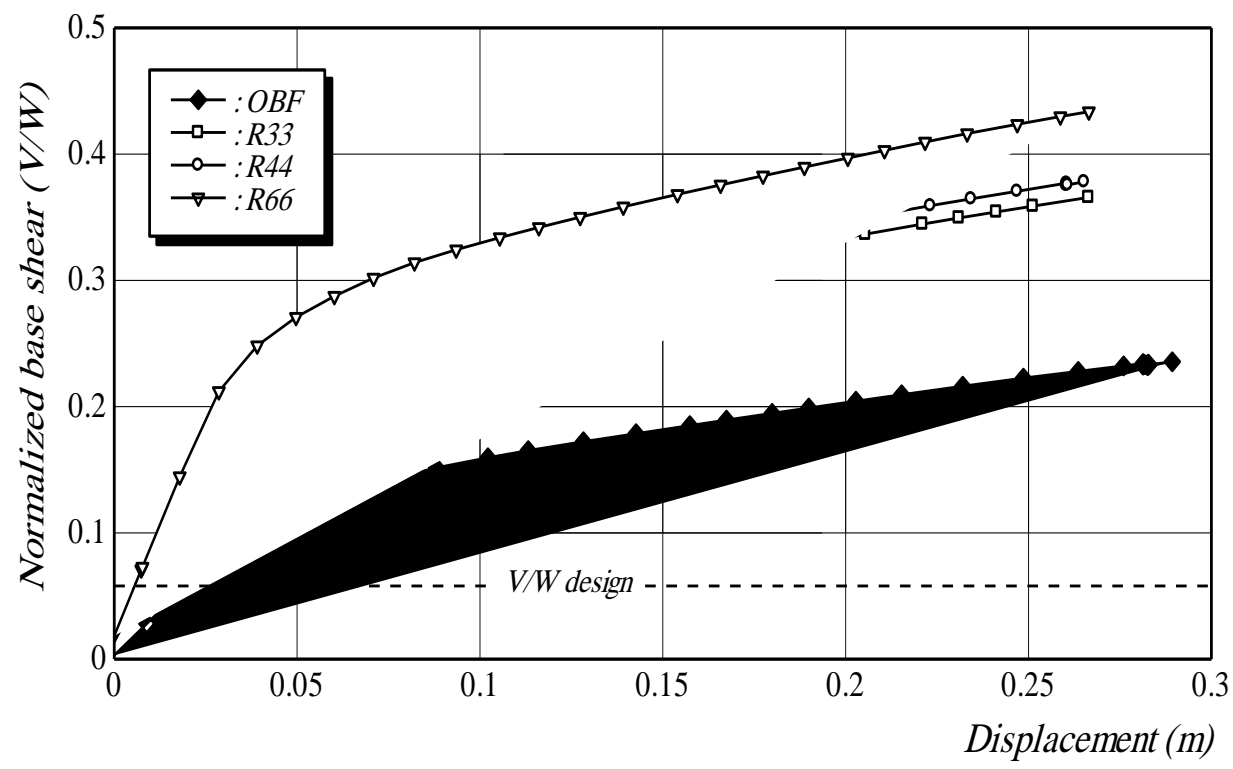

Fig. 6 : Effect of MI wall configurations (SW- MRF building)

On the contrary, for SW-MRF buildings, the opening size has minor effect on the building displacement capacity. The percentage increase in peak building displacement capacity for buildings with different opening sizes relative to corresponding configuration with solid MI does not exceed $5.85 \%$. Related to the maximum normalized base shear, it is found that the influence of opening sizes is close for both building types, MRF and SW-MRF, and is inversely proportional to the opening size. The percentage reduction in the stiffness, related to same configuration with solid MI walls ranges between $14.6 \%$ and $27.6 \%$ for MRF building while this ratio ranges between $12.17 \%$ and $27.6 \%$ for SW-MRF building. 


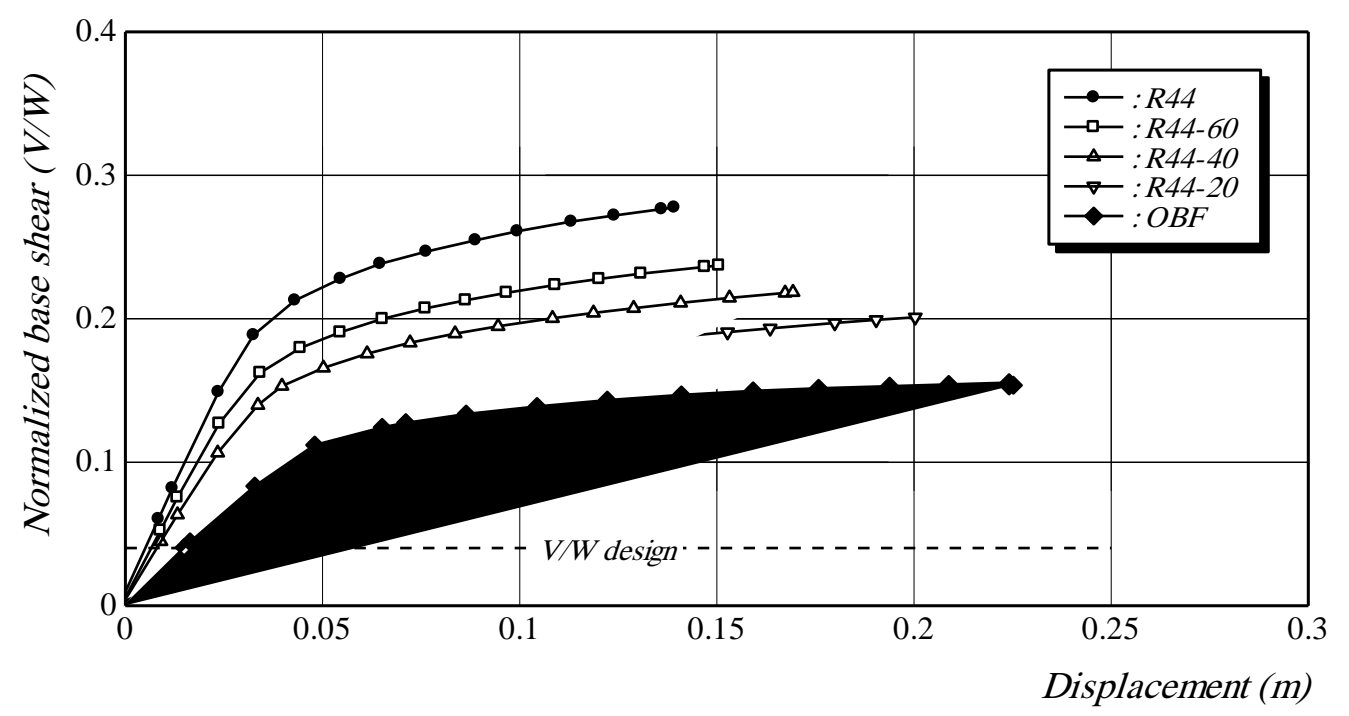

Fig. 7 : Effect of MI walls opening sizes (MRF building)

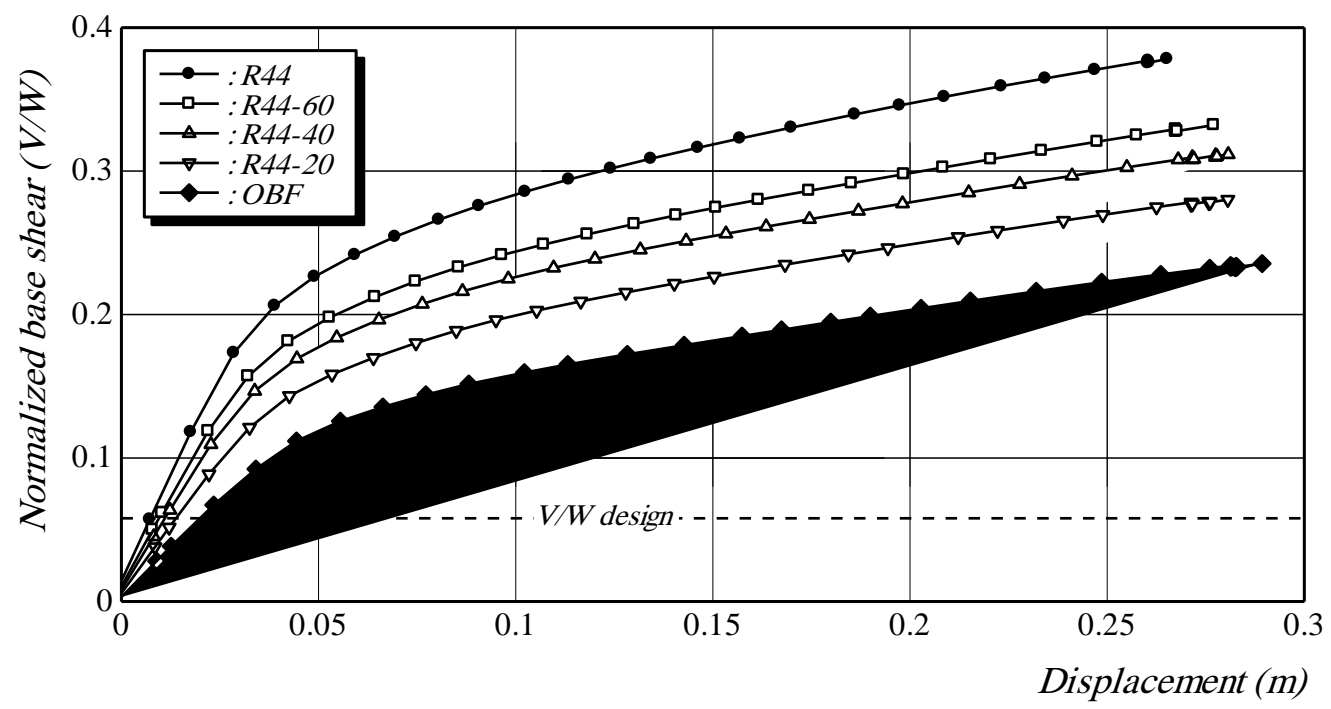

Fig. 8 : Effect of MI walls opening sizes (SW-MRF building)

The influence of the absence of MI walls in the first storey, which is commonly used in residential and commercial buildings, forming what is called (first soft storey) is studied. The results of different configurations with $\left(\mathrm{N}_{\mathrm{i}} / \mathrm{N}_{\mathrm{t}}\right)$ equal to $33.33 \%, 44.44 \%$ and $66.67 \%$ having opening size generates a stiffness reduction factor of $40 \%$ for the two considered building types are shown in Figs. 9 and 10. It can be found that the absence of walls in the first storey while applying them in the rest of stories, can negatively alter the lateral response of MRF buildings. Compared to the reference $O B F$ case, MI walls could increase the peak shear wall capacity of the mentioned MRF building by values range between $2.67 \%$ and $16.90 \%$ for the different configurations, arranged from $R 33-40 S$ to R66-40S, respectively. This minor 
increase in the building normalized base shear capacity is associated with a drastic reduction in the nonlinear displacement capacity and hence building ductility. The reduction in nonlinear displacement relative to the reference $O B F$ sample case ranges between $39.47 \%$ to $49.55 \%$ for cases $R 33-40 S$ and $R 66-40 S$, respectively. For more illustration, a comparison could be made also between sample cases with and without regular infills as cases $R 44-40$ and $R 44-40 S$, for example. This comparison results in that there is a reduction in both maximum normalized base shear and nonlinear peak displacement of $21.6 \%$ and $24.0 \%$, respectively due to the absence of MI walls in the first storey.

Discussing the results of the preceded sample cases but for SW-MRF buildings yields that, again, it is clear that the existence of uniform RC shear walls has a great influence in controlling the nonlinear displacement capacity when applying irregular MI walls lead to first soft storey. The maximum reduction in the nonlinear displacement associated with any of the masonry infilled building cases relative to the reference $O B F$ building does not exceed $9.5 \%$. Carrying out a comparison between two cases of building type SW-MRF with regular and irregular infill walls as cases $R 44-40$ and $R 44-40 S$, its found that the values of nonlinear displacement is almost the same while the percentage reduction in normalized base share does not exceed $3.5 \%$.

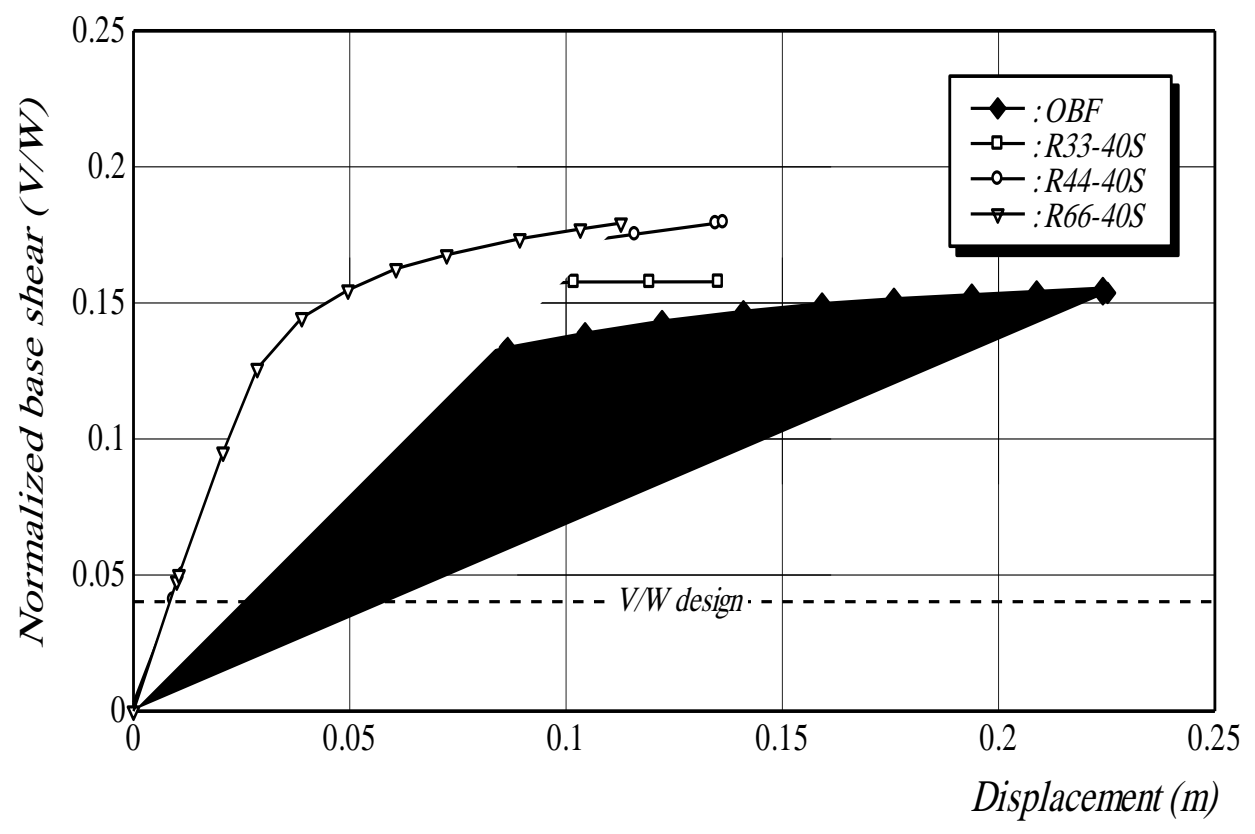

Fig. 9 : Effect of absence of MI walls in the first storey (MRF building) 


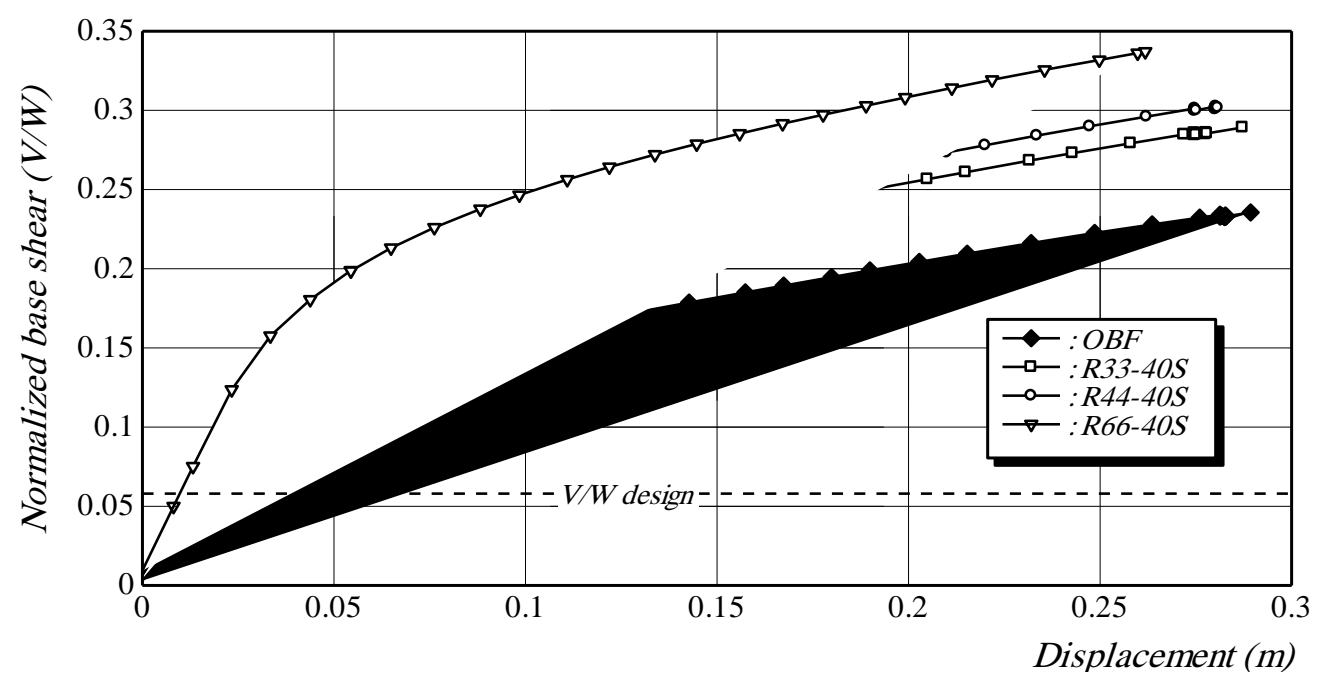

Fig. 10 : Effect of absence of MI walls in the first storey (SW-MRF building)

The effect of the thickness of MI walls, either $0.12 \mathrm{~m}$ or $0.20 \mathrm{~m}$, on the lateral response of infilled frames is studied. The obtained nonlinear push-over results for example cases $R 44-40$ with either mentioned MI wall thicknesses are compared as shown in Fig. 11. It is found that the effect of MI wall thickness is almost minor. Generally, increasing the MI wall thickness relatively increases the lateral stiffness while decreasing their ductility. It is also still observed that the influence of MI wall thickness is more pronounced for MRF buildings than SW-MRF buildings. The percentage changes in the results due to changing the infill thickness from 0.12 to 0.2 are increase in (V/W) of about $10.0 \%$ and $7.3 \%$ for MRF and SW-MRF buildings, respectively while the percentage reduction in the nonlinear displacement capacity is about $14.35 \%$ and $2.90 \%$ for the preceded mentioned building types, respectively.

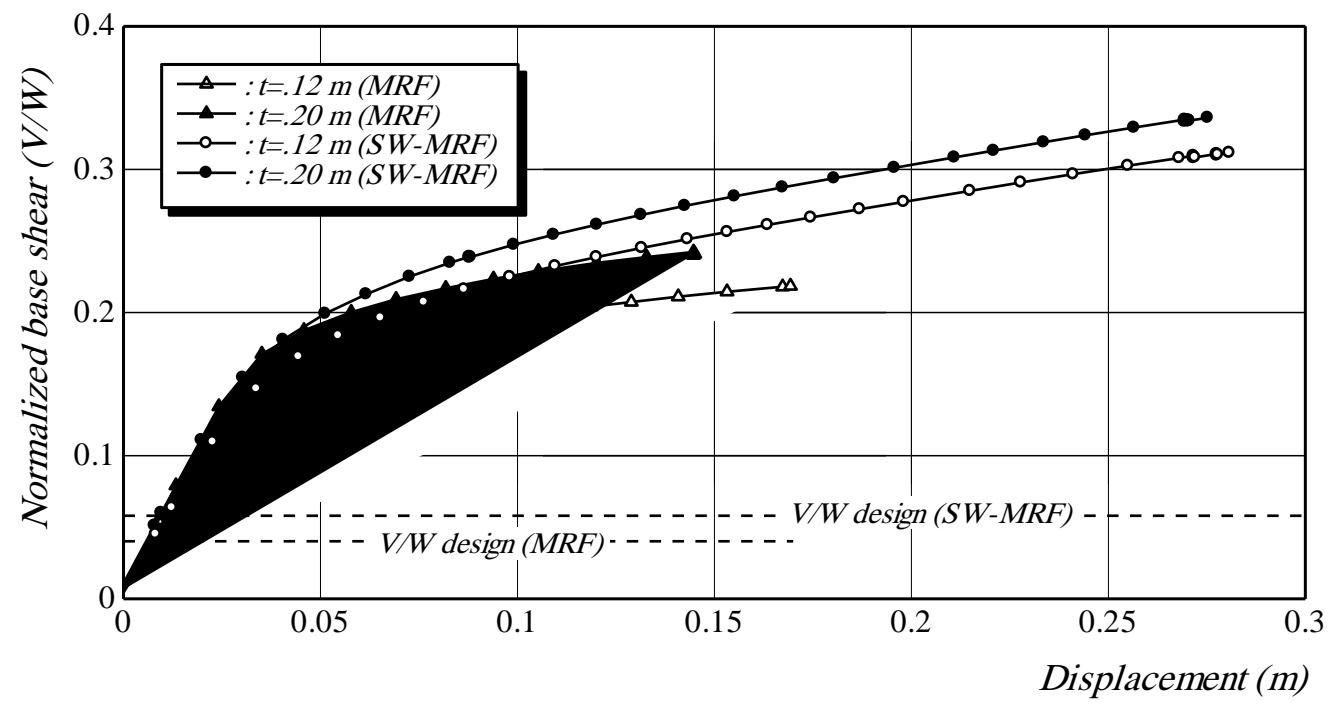

Fig. 11 : Effect of MI wall thickness 


\section{6- NONLINEAR ANALYSIS OF DIFFERENT HEIGHT BUILDINGS}

The behavior of selected MI wall properties implemented in SW-MRF buildings with different heights ranging between 9 and 20 floors in comparison to the reference $O B F$ example study buildings is studied. The results are shown in Figs. 12 to 14. It can be observed that the ratio between the first yield normalized base shear and the designed one for $O B F$ buildings with different heights ranges between 1.20 and 1.96. Considering MI walls with ( $\mathrm{Ni} / \mathrm{Nt}$ ) value equal to $44.44 \%$ and with opening sizes give stiffness reduction factor $\lambda$ of $40 \%$, the preceded mentioned ratios of first yield to design base shear value increase to a range between 1.64 and 2.71 .

The general behavior of either $O B F$ or masonry infilled buildings is that the normalized base shear highly decreases as the building height increases. In contrary to that behavior, the nonlinear displacement capacity increases as the building height increases. Investigating the lateral effect of MI walls on SW-MRF buildings with variable heights leads to that there is increase in the maximum normalized base shear capacity due to the consideration of MI walls. The percentage increase in maximum (V/W) is adversely proportional to the building height and is equal to $25.29 \%$, $17.25 \%, 15.18 \%$ and $14.28 \%$ for buildings with number of floors equal to $9,12,16$ and 20, respectively. Regarding the maximum nonlinear displacement capacity, it is found that there is reduction in the obtained values associated with implementing MI walls. This reduction is proportional to the height of building. The percentage reduction in the maximum displacement capacity relative to the $O B F$ bare frame building is obtained to be $3.97 \%, 13.83 \%, 21.75 \%$ and $22.63 \%$ for buildings with floor numbers ranging between 9 and 20 floors, respectively. This means that due to the implementation of MI walls, the gain in normalized base shear is inversely proportional to building height. On the contrary, the reduction in maximum nonlinear displacement is proportional to building height. It is also remarkable that the slope of the normalized push-over curves increases as the number of floors decreases.

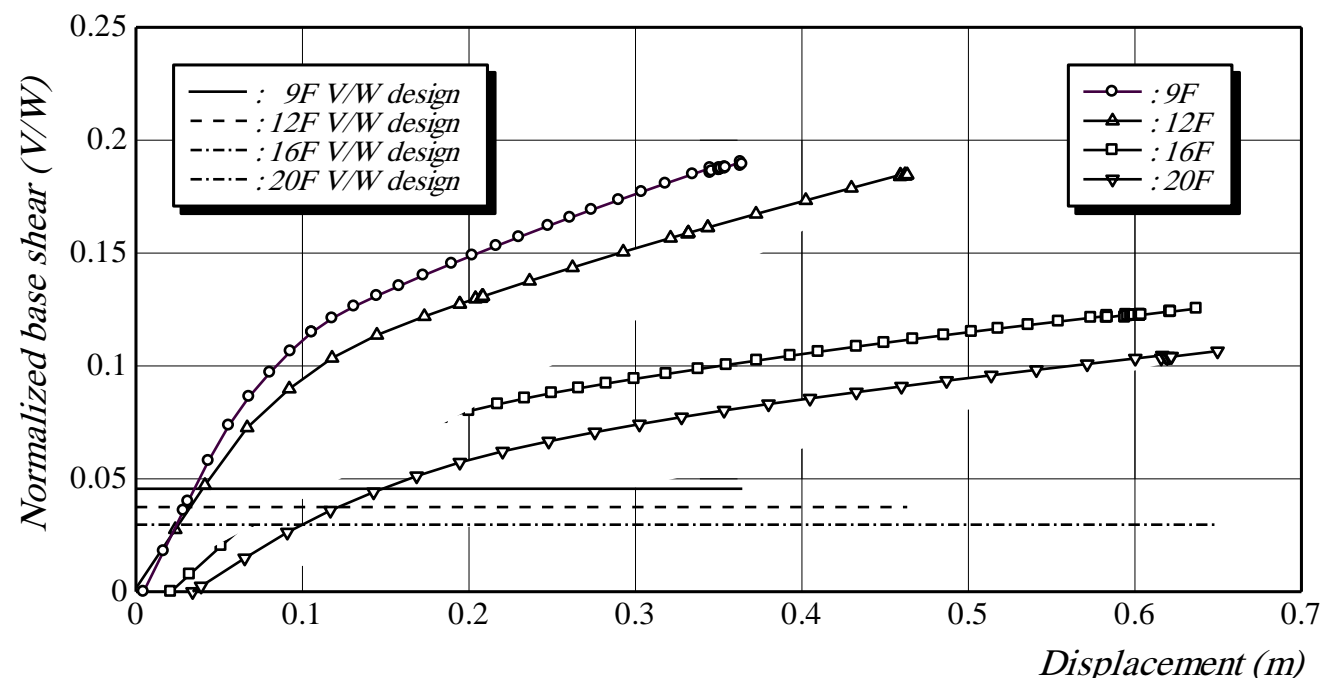

Fig. 12 : Lateral response of $O B F$ buildings with different heights 


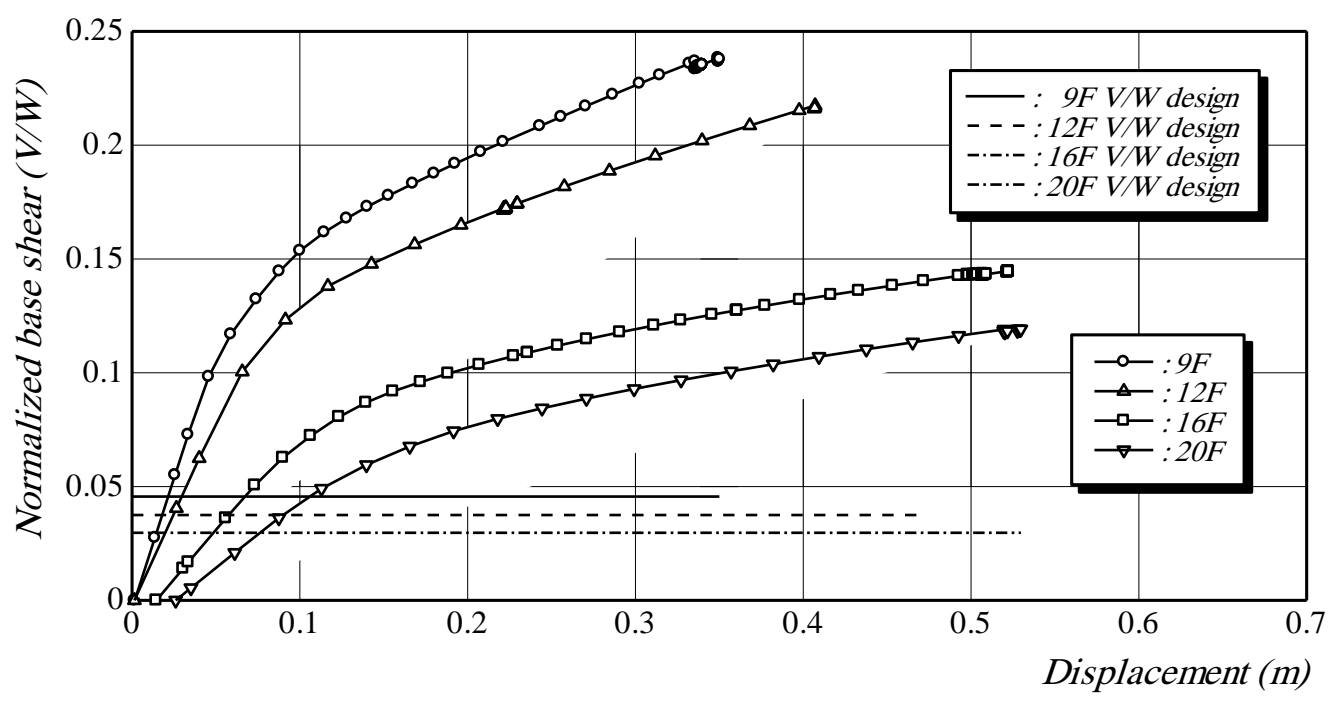

Fig. 13 : Effect of MI walls on buildings with different heights

The influence of SW-MRF building height on some properties of the MI walls as opening sizes, soft first storey and wall thickness is also investigated. It was obvious that the difference in results due to the variation of any of these wall properties and parameters decreases as the height of SW-MRF building increases. Taking SW-MRF building with (Ni / Nt ) value equal to $44.44 \%$ as a case example. It is found that if the MI walls stiffness reduction factor, related to the opening size, changes from $20 \%$ to $60 \%$ the percentage increase in stiffness is $13.5 \%$ for 12 floors buildings while it is $12.0 \%$ for 20 floors building, this behavior is shown in Fig. 14. The lateral response of buildings with either regular and irregular infills (first soft storey) comes closer as the building height increases till they are almost identical for 20 floors building. Also, changing the wall thickness from $0.12 \mathrm{~m}$ to $0.2 \mathrm{~m}$ results in an increase in stiffness of about $7.6 \%$ for 12 floors building and $5.0 \%$ for 20 floors building.

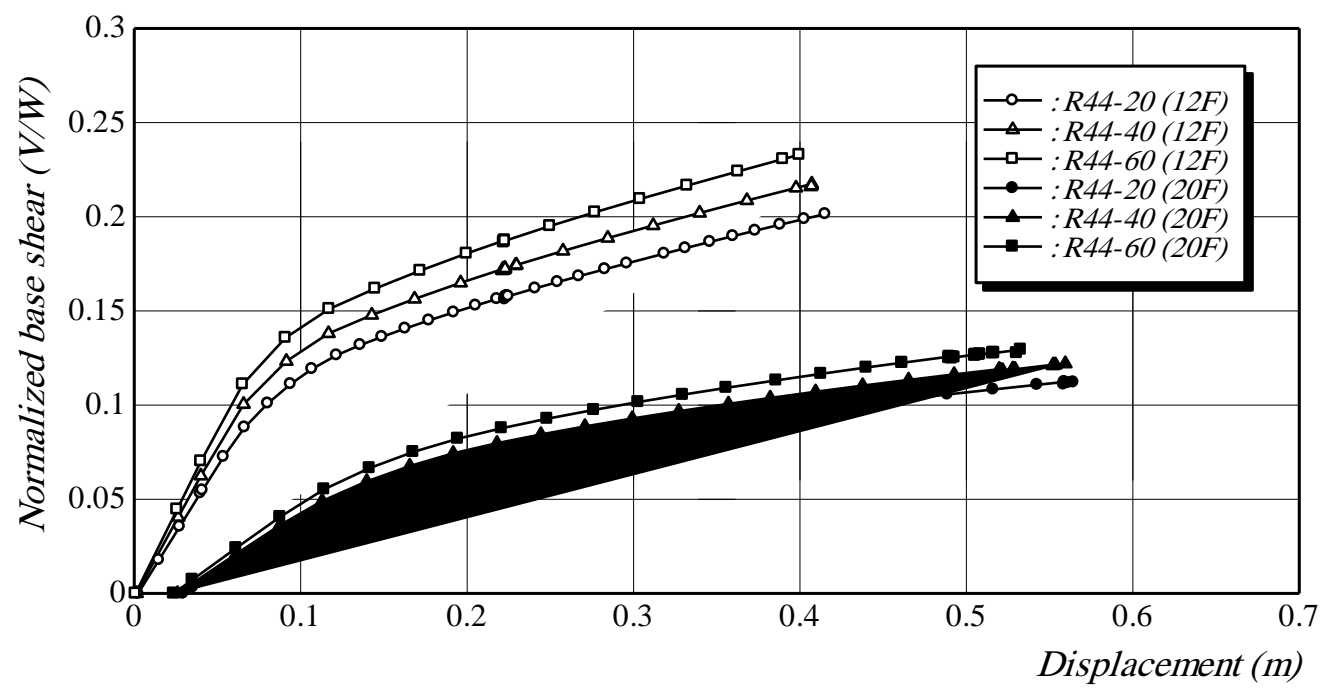

Fig. 14 : Effect of MI wall opening sizes on buildings with different heights 


\section{7- FORMATION OF PLASTIC HINGES AND FAILURE MECHANISM}

The propagation and formation of plastic hinges $(\mathrm{PH})$ in different members as columns, beams and MI walls of the different example buildings, in this study, depend on the the ATC-40 [ 26] guidelines. As shown in Fig. 15, five points labeled A, B, C, D and E are used to define the force deflection behavior of the hinge and three points labeled IO, LS and CP are used to define the acceptance criteria of the hinge. (IO, LS and CP stand for Immediate Occupancy, Life Safety and Collapse Prevention, respectively). The values assigned to each of these points vary depending on the type of member as well as many other parameters defined in the guidelines.

The formation of $\mathrm{PH}$ in the $O B F$ of building type MRF is first discussed. It is found that the ratio of columns suffer from $\mathrm{PH}$ to the total ones is more than $75.0 \%$, of which about $54.0 \%$ have plastic hinge of limits (LS-CP). The rest of building columns suffer from PH of less risk which are within the limits (IO-LS) and (B-IO). The ratio of beams with $\mathrm{PH}$ is much less than this of the columns as only the beams in the lateral direction are affected by the push-over forces. About $17.0 \%$ of building beams have $\mathrm{PH}$, out of them $53.0 \%$ within limits (LS-CP). This behavior is shown in Fig. 16 (a).

The consideration of solid infill wall, without openings, could change the $\mathrm{PH}$ mechanism for the corresponding $O B F$ building. Discussing, for example, MRF building with solid MI walls of configuration R44 as shown in Fig. 16 (b), the number of columns with $\mathrm{PH}$ is relatively reduced to become $71.0 \%$. The real influence is revealed in that out of these columns with $\mathrm{PH}$, less than $20 \%$ are within the limits (LS-CP). The reduction in number and limits of PH comes at the expense of MI walls, $82 \%$ of these MI walls suffer from PH, about $18 \%$ out of them completely failed. The failure mechanisms of masonry infilled MRF buildings with MI walls openings is illustrated for sample building with infill properties $R 44-40$ as shown Fig. 16 (c). The existence of openings in the MI walls affect the formation of $\mathrm{PH}$ in columns by minor reduction in the number of columns with $\mathrm{PH}$ to be about $65 \%$ of columns but increases the number of columns with PH of limits (LS-CP) to be $35 \%$. The failure mechanism for both beams and infill walls is similar to the corresponding case with solid MI walls.

The $\mathrm{PH}$ formation and failure mechanism for cases with soft first storey due to the absence of MI walls in this storey is discussed for case R44-40. The response is remarkable by the lateral nonlinear displacement of the first storey which is about $63.9 \%$ of the maximum building displacement located in the top floor of building, noting that this ratio for the corresponding $O B F$ does not exceed $39.2 \%$. This behavior can be easily observed from Fig. 16 (d). It is also found that although the ratio of columns with PH is only $43.0 \%$ out of which about $29.6 \%$ within the limits (LS-CP), almost all the columns of the first floor have PH within this limit. The number of MI walls having PH is about $59.0 \%, 10.0 \%$ of which completely failed.

The failure mechanism for different cases of SW-MRF buildings with 6 floors is also discussed for variety of cases. The PH behavior of $O B F$ is first discussed and found to be different from the behavior of corresponding MRF building in that the total ratio of columns with $\mathrm{PH}$ highly increases to be $92.4 \%$, out of this ratio about $72.5 \%$ of columns have PH within the limits (LS-CP) while $1.5 \%$ failed. This behavior is illustrated in Fig. 17 (a). The existence of MI walls does not highly affect the number of columns with PH but affects the type of PH. Considering, for example, cases with 
MI wall configurations $R 44$ and $R 44-40$, it is found that the ratio of columns with $\mathrm{PH}$ within the limits (LS-CP) decreased to be about $62.0 \%$. Similar PH mechanism are obtained for the MI walls for the mentioned example cases. About $97.0 \%$ of MI walls experienced plastic hinges, out of them about $68.0 \%$ with PH within the limits (LS-CP) while about $7.5 \%$ of them failed completely as illustrated in Fig. 17 (b).

The effect of building height on the failure mechanism is also illustrated for some selected sample cases with 12 and 20 floors. It is found that as the height of building increases the ratio of $O B F$ columns with $\mathrm{PH}$ to the total columns decreases. For example while this ratio is $73.3 \%$ for 12 floors building it decreases to reach $46.9 \%$ for 20 floors building. Most of the observed column PH are within the limits (B-IO). The consideration of infill walls, as case $R 44-40$, could reduce the number of columns with $\mathrm{PH}$ to be $52.0 \%$ and $34.0 \%$ for 12 and 20 floor buildings, respectively. This enhancement of column PH comes at the expense of the MI walls, $95.5 \%$ of MI walls suffer $\mathrm{PH}$, of which $3.6 \%$ completely collapsed. The corresponding ratio for 20 floor buildings are $95.0 \%$ of which $46.0 \%$ completely failed.

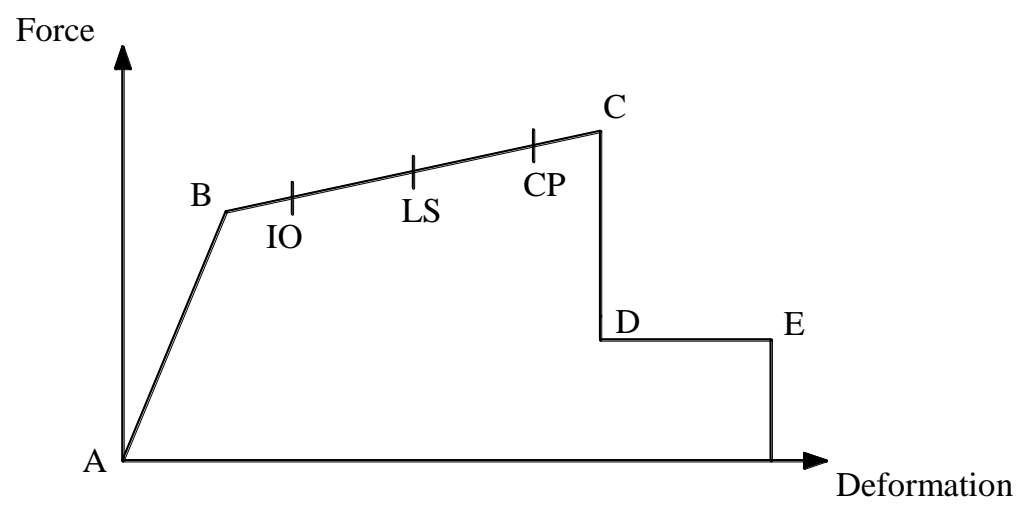

Fig. 15 : Force-deformation for $\mathrm{PH}$ limits
- (B-IO)
- (IO-LS)
(LS-CP)
$\Delta(\mathrm{D}-\mathrm{E})$

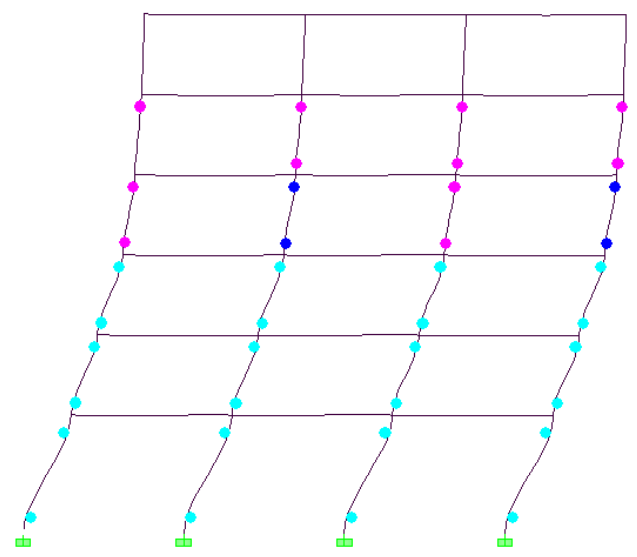

(a) $O B F$ building

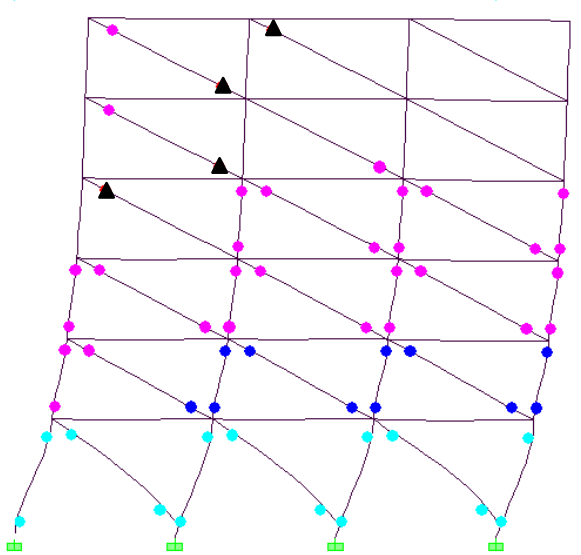

( b) $R 44$ building

Fig. 16 : Examples of PH formation for MRF buildings 


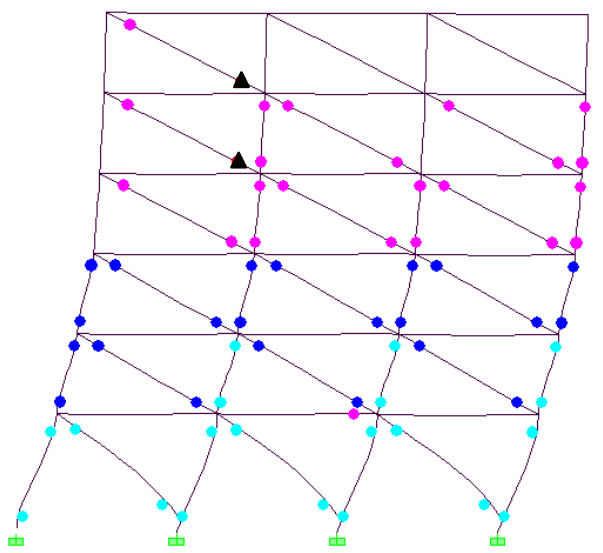

(c) $R 44-40$ building

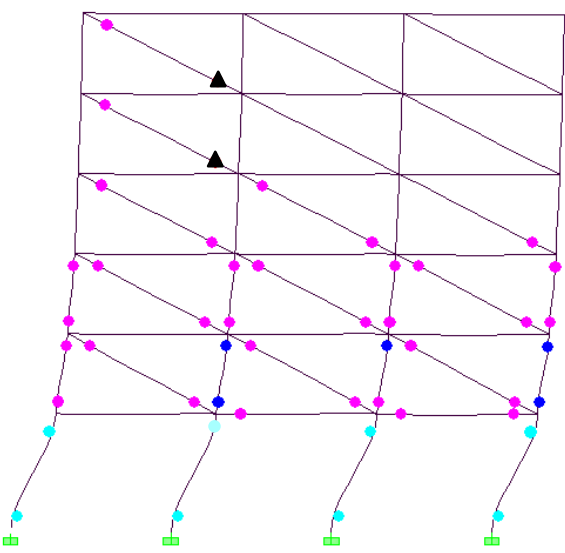

(d) $R 44-40 S$ building

Fig. 16 (cont.) : Examples of PH formation for MRF buildings

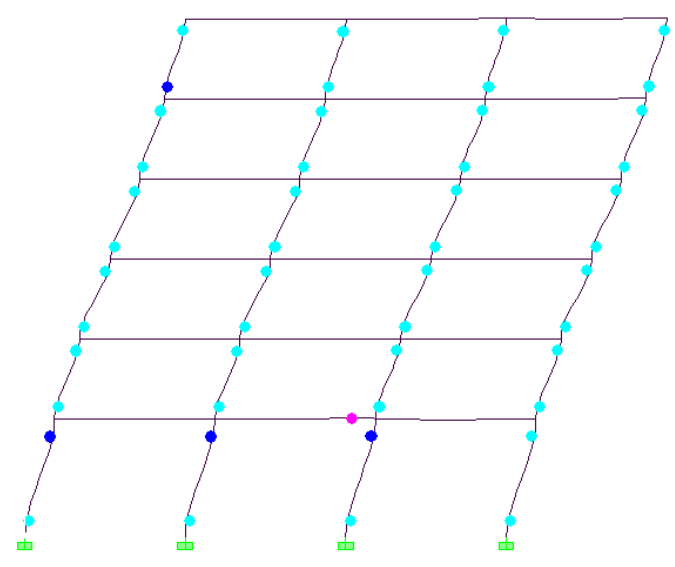

(a) $O B F$ building

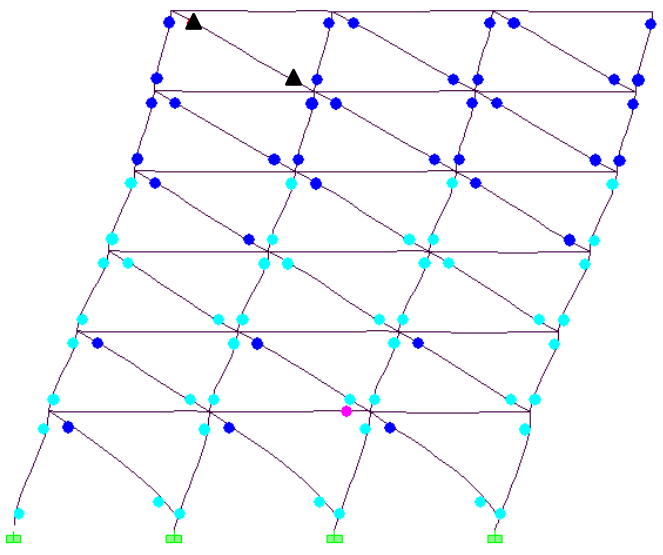

(d) $R 44-40$ building

Fig. 17 : Examples of PH formation for SW-MRF buildings

\section{CONCLUSIONS}

A nonlinear lateral response analysis is carried out to investigate the effect of MI walls when applied to buildings of different lateral load resisting systems as MRF or SWMRF buildings. A variety of MI wall parameters are considered. These parameters include the number of panels occupied with MI walls to total panels in lateral direction $\left(\mathrm{N}_{\mathrm{i}} / \mathrm{N}_{\mathrm{t}}\right)$, different infill opening sizes, creation of soft first storey and MI wall thickness. The effect of building height is also studied through investigating SW-MRF buildings with five different heights. Based on the results obtained from this analytical study, the following conclusions could be drawn out.

1) The influence of MI walls on the lateral response of buildings should not be simply neglected. MI walls can significantly change the lateral response of RC framed 
buildings to which they are applied. Solid MI walls regularly distributed over the building height can highly increase the peak base shear capacity to values up to $113.0 \%$ and $84.0 \%$ for MRF, and SW - MRF buildings, respectively.

2) Although MI walls have relatively similar contribution to lateral stiffness of either MRF or SW-MRF buildings, its influence on peak nonlinear displacement capacity is significantly affected by the type of building. While they can drastically reduce the displacement capacity of MRF buildings to values up to $50.0 \%$, the existence of uniform RC shear walls can highly restrict the reduction of peak displacement capacity to less than $8.0 \%$.

3) The most influential MI wall parameter is where a soft first storey is generated in MRF buildings due to omitting the MI walls from the first storey while applying them to the rest of stories. While a tiny gain could be achieved in stiffness, a drastic reduction could occur to displacement capacity. For an example case, an increase in base shear capacity of less than $3.0 \%$ was associated by a reduction in peak displacement capacity of about $40.0 \%$.

4) The effect of masonry wall configurations represented by the number of bays occupied with MI to total bay numbers in the lateral direction $\quad\left(\mathrm{N}_{\mathrm{i}} / \mathrm{N}_{\mathrm{t}}\right)$ along with the opening size were the second important parameters affecting infilled frames. These two parameters could significantly alter the building capacity for both MRF and SW-MRF buildings and negatively affect the ductility of MRF buildings.

5) Masonry infill walls with small thickness equal $0.12 \mathrm{~m}$ can significantly alter the response of the buildings, either MRF or SW-MRF, to which they are applied. The variation of masonry infill wall thickness between $0.12 \mathrm{~m}$ and $0.2 \mathrm{~m}$ yields relatively, minor change in the results of nonlinear lateral response.

6) The building height parameter is found to affect the results of masonry infilled buildings in a manner that the percentage increase in stiffness due to the contribution of MI walls is inversely proportional to the building height. In contrary to this, the reduction in displacement capacity is proportional to the building height. The effect of parameters as opening size, first soft storey and wall thickness fades as the building height increases.

7) MI walls can highly change the distribution of damage within the structure. Generally, The existence of MI walls could enhance the plasticity of building columns but this comes on the expense of MI walls. Most of MI walls of the studied example buildings suffer from plasticity with variable limits.

8) The new edition of the 2008 ECOL renewed some general provisions related to the matter of MI walls (called non structural elements in this code). Detailed provisions need to be included about some MI wall aspects as modeling methodology, effect of infill parameters as soft first storey and openings in infill walls.

\section{REFERENCES}

1- Flanagan, R.D., Bennett, R.M.: “ In-plane Behavior of Structural Clay Tile Infilled Frames " Journal of Structural Engineering, Vol. 125, No. 6, pp. 590-599, 1999. 
2- Hao, H., Ma, G., Lu, Y.: "Damage Assessment of Masonry Infilled RC Frames Subjected to Blasting Induced Ground Excitations " Journal of Engineering Structures, Vol. 24, pp. 799-809, 2002.

3- Kormaz, K.A., Demir, F., Sivri, M.: “ Earthquake Assessment of R/C Structures with Masonry Infill Walls " International Journal of Science \& Technology, Volume 2, No. 2, pp. 155-164, 2007.

4- Kaushik, H.B., Rai, D.C., Jain, S.K.: " Code Approaches to Seismic Design of Masonry-Infilled Reinforced Concrete Frames: A State-of-the-Art Review " Journal of Earthquake Spectra, Vol. 22, pp. 961-983, 2006.

5- Jain, S.K., Mondral, G.: " Lateral Stiffness of Masonry Infilled Reinforced Concrete (RC) Frames with Central Opening " Journal of Earthquake Spectra, Vol. 24, pp. 701-723, 2008.

6- Fajfar, P., Dolsek, M.: “ Soft Storey Effects in Uniformly Infilled Reinforced Concrete Frames "Journal of Earthquake Engineering, Vol. 5, pp. 1-12, 2001.

7- Beall, C., Jaffe, R.: "Concrete and Masonry Data Book" McGraw-Hill, 2003.

8- Arslan, M.H., Korkmaz, H.H.: “ What Is to Be Learned from Damage and Failure of Reinforced Concrete Structures During Recent Earthquakes in Turkey " Journal of Engineering Failure Analysis, Vol. 14, , pp. 1-22, 2007.

9- Dogangun, A.: " Performance of Reinforced Concrete Buildings during the May 1, 2003 Bingol Earthquake in Turkey" Journal of Engineering Structures, Vol. 26, pp. 841-856, 2004.

10- " The Egyptian Code for Calculation of Loads and Forces in Structural and Building Work, ECL 201 "Housing and Building Research Center, Cairo, Egypt, September 2008.

11- Smith, B.S.: " Lateral Stiffness of Infilled Frames" Journal of Structural Division, Vol. 88, No. 6, pp. 183-199, 1962.

12- Mainstone, R. J.: “' Supplementary Note on the Stiffness and Strength of Infilled Frames.' Building Research Station, Garston, Watford, 1974.

13- Al-Chaar, G., Issa, M.: “ Behavior of Masonry-Infilled Nonductile Reinforced Concrete Frames" Journal of Structural Engineering, Vol. 128, No. 8, pp. 1055-1063, 2002.

14- Klingener, R. E., Bertero, V. V.: “ Earthquake Resistance of Infilled Frames ” Journal of Structural Division, Vol. 104, No. 6, pp. 973-989, 1978.

15- Asteris, P.G.: " Lateral Stiffness of Brick Masonry Infilled Plane Frames " Journal of Structural Engineering, Vol. 129, No. 8, pp. 1071-1079, 2003.

16- Kose, M.M.: "Parameters Affecting the Fundamental Period of RC buildings with Infill Walls" Journal of Engineering Structures, Vol. 31, pp. 93-102, 2009.

17- Abo El-Wafa, W.M.: " Effect of Masonry Infill Walls on the Natural Period of Reinforced Concrete Buildings" Journal of Engineering Science, Assiut University, Vol. 37, No.1, 2009.

18- Sobaih, M., Abdin, M.M.: “ Seismic Analysis of Infilled Reinforced Concrete Frames" Computer \& Structures, Vol. 30, No. 3, pp. 457 - 464, 19888.

19- Das, D., Murty, C.V.R.: “ Brick Masonry Infills in Seismic Design of RC Framed Buildings: Part 1 - Cost implications" The Indian Concrete Journal, pp. 39 - 43, July 2004. 
20- Dolsek, M., Fajfar, P.: " The Effect of Masonry Infills on the Seismic Response of a Four Soft Storey Reinforced Concrete Frame - a probabilistic assessment" Journal of Engineering Structures, Vol. 30, pp. 3186 -3192, 2008.

21- Bell, D.K., Davidson, B.J.: " Earthquake Assessment of R/C Structures with Masonry Infill Panels" NZSEE 2001 Conference, Paper No.4.02.01, 2001.

22- " ETABS, Nonlinear version 9 Beta, Extended 3-D Analysis of Building Systems" Computers \& Structures, Inc., Berkeley, U.S.A., 2005.

23- Eurocode-8: "Design of Structures for Earthquake Resistance" The European Committee for Standardization, Final Draft, December 2003.

24- FEMA - 306: "Evaluation of Earthquake Damaged Concrete and Masonry Wall Buildings - Basic Procedures Manual "Federal Emergency Management Agency, 1999.

25- FEMA - 273, "NEHRP Guidelines for the Seismic Rehabilitation of Buildings" FEMA 273, Federal Emergency Management Agency, 1997.

26- Applied Technology Council: "Seismic Evaluation and Retrofit of Concrete Buildings" Vol. 1. Washington, DC, USA: ATC- 40, 1996.

\section{السلوك العرضي اللاخطي للمباني الخرسانية المسلحة ذات حوائط بناء مختلفة الخصائص}

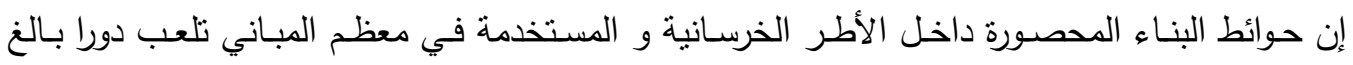

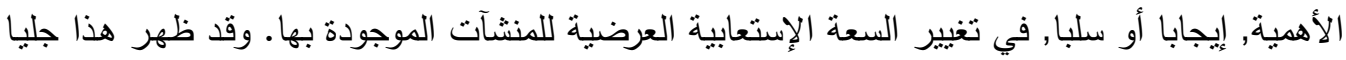

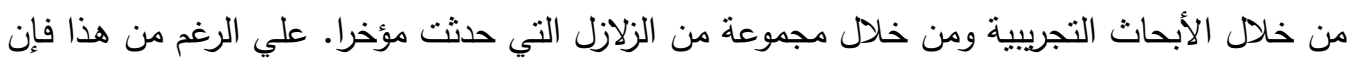

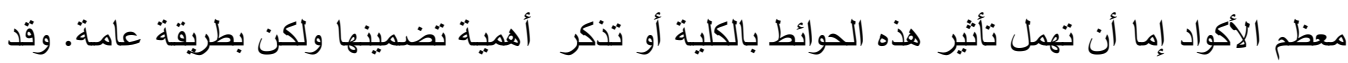

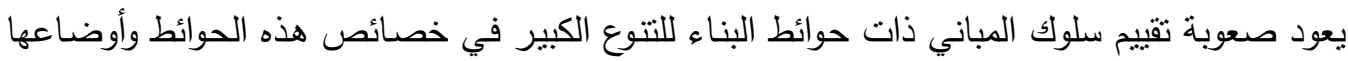
المختلفة وما قد يكون بها من فتحات وعدم وجودها في الطابق الأول وسمكها وغيره.

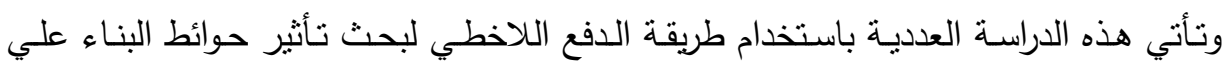

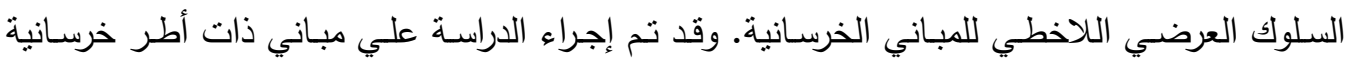

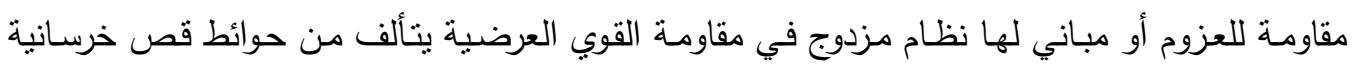
بالإضافة إلي الأطر المقاومة للعزوم. وقد تم تطوير نموذج مبسط لتمثيل السلوك اللاخطي لحوائط البناء

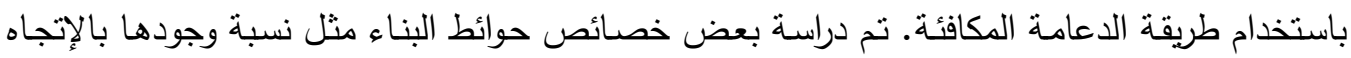
العرضي, وجود فتحات بالحوائط ومساحاتها المختلفة, عدم وجود حوائط بناء بالطابق الأرضي في في حين لئن

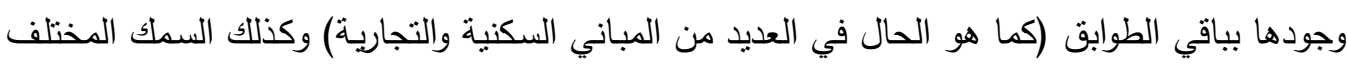

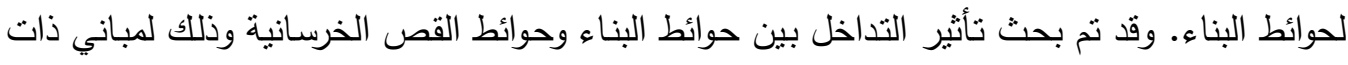

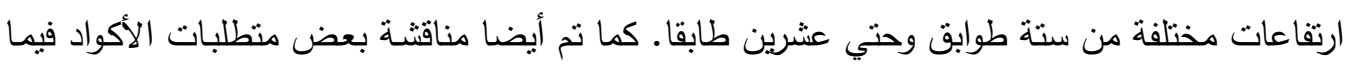
يخص حوائط البناء. 
ومن خلال النتائج التي تم الحصول عليها وجد أنه يجب ألا ينت إهمال نأثير حوائط البناء لما لها من أهمية بالغة علي السلوك العرضي للمباني الخرسانية الموجودة بها حيث وجد أنها قد تؤدي إلي الي إحداث زيادة كبيرة في سعة القص للمبني وصلت إلي 113\% في حالة المباني ذات الأطر الخرسانية و

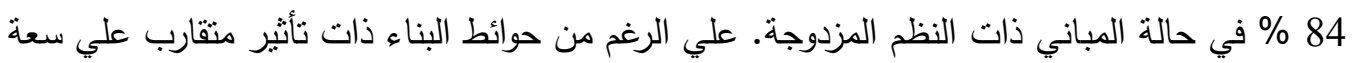

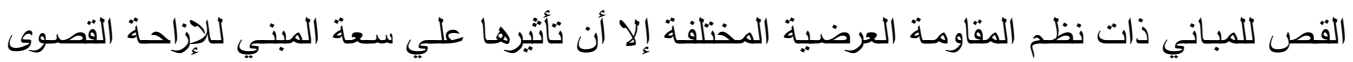
يعتمد علي نوع المبني حيث أن حوائط القص الخرسانية لها قدرة عالية علي كبح هذا التأثير السلبي

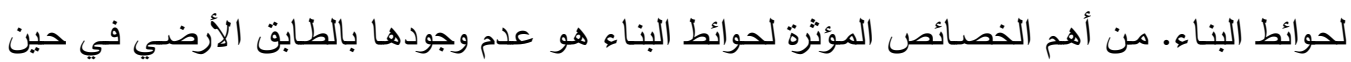

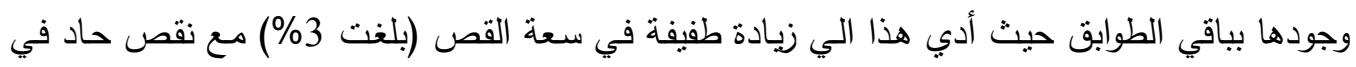

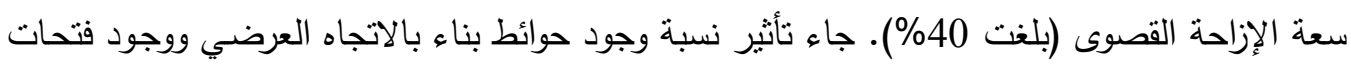
بالحوائط ومساحاتها المختلفة في المرتبة الثانية من حيث الأهمية. وقد وجد أن حوائط البناء ذات أنات السمك الأدنى (12 سم) لها تأثثر فعال علي سلوك المبني حيث أن تتوع سمك الحوائط كان هو الأقل تأثنيرا.

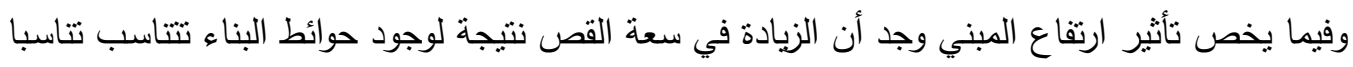

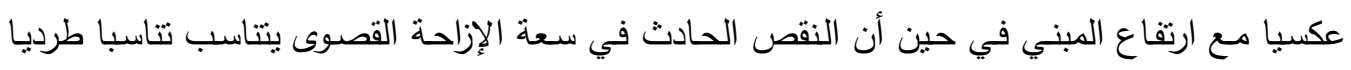

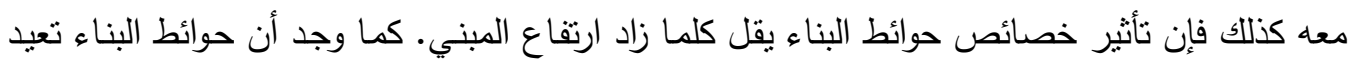

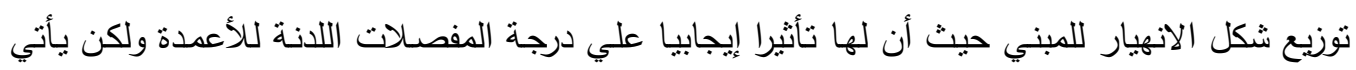

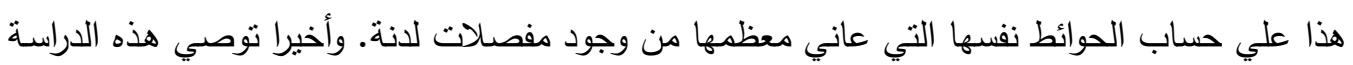

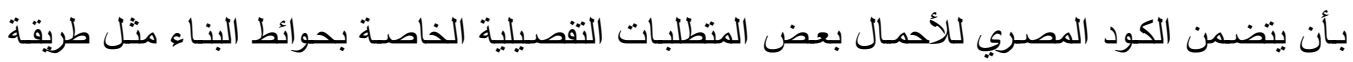
تمثيلها وتأثير الفتحات بها وتأثثر عدم وجودها في الطابق الأرضي. 